\title{
NF-KB decoy potentiates the effects of radiation on vascular smooth muscle cells by enhancing apoptosis
}

\author{
Shu-Ying Zhang ${ }^{2 *}$, Kyung-Woo Park ${ }^{1,2 *}$, \\ Seil $O h^{1,2}$, Hyun-Ju Cho ${ }^{2}$, \\ Hyun-Jai Cho ${ }^{1,2}$, Jin-Shik Park ${ }^{1,2}$, \\ Young-Seok Cho ${ }^{1,2}$, Bon-Kwon Koo ${ }^{1,2}$, \\ In-Ho Chae ${ }^{1,2}$, Dong-Joo Choi ${ }^{1,2}$, \\ Hyo-Soo Kim ${ }^{1,2,3}$ and Myoung-Mook Lee Len $^{1,2}$ \\ ${ }^{1}$ Department of Internal Medicine \\ Seoul National University College of Medicine \\ Seoul 110-744, Korea \\ ${ }^{2}$ Cardiovascular Laboratory \\ Clinical Research Institute \\ Seoul National University Hospital \\ Seoul 110-744, Korea \\ ${ }^{3}$ Corresponding author: Tel, 82-2-2072-2226; \\ Fax, 82-2-766-8904; E-mail, hyosoo@snu.ac.kr \\ *These authors contributed equally to this work. \\ Accepted 12 January 2005
}

Abbreviations: MTT, 3-(4,5-dimethylthiazol-2-yl)-2,5-diphenyl-2H-tetrazoliumbromide; VSMC, vascular smooth muscle cell

\begin{abstract}
NF- $\kappa B$ promotes cell survival against external stress such as radiation. We examined whether $N F-\kappa B$ decoy transfection enhances the antiproliferative effects of radiation on vascular smooth muscle cells (VSMCs) in vitro. The irradiation induced activation or nuclear translocation of NF-kB p65 in VSMCs was confirmed by immunofluorescence. $N F-K B$ decoy transfection resulted in inhibition of the radiation-induced NF-KB activation in VSMCs and the subsequent reduction of transcription and translocation of ICAM, iNOS, and TNF- $\alpha$, downstream molecules under the control of NF-kB. By using MTT assay, NF- $\kappa B$ decoy augmented the antiproliferative effects of radiation, where the effect of low dose radiation (2 and 8-Gy) of the cells transfected with NF-KB decoy was equivalent to the high dose (16-Gy) irradiated non-transfected cells at $48 \mathrm{~h}$ after irradiation: $1.06 \pm 0.16, \quad 1.11 \pm 0.22, \quad 1.20 \pm 0.25$, respectively. The decrease in proliferation and survival of the radiation treated cells by flow cytometry analysis showed that NF-KB inhibition
\end{abstract}

did not show any additive effects on the cell cycle of the irradiated VSMCs, while apoptosis was significantly increased after NF- $\kappa B$ decoy transfection in the irradiated VSMCs (apoptosis fraction: $13.33 \pm 2.08 \%$ vs. $26.29 \pm 7.43 \%$, for radiation only vs. radiation $+N F-\kappa B$ decoy transfection, $P<0.05)$. In addition, at $48 \mathrm{~h}, N F-\kappa B$ decoy transfection dose dependently $(10 \mu \mathrm{M}$ vs. $20 \mu \mathrm{M}$ ) inhibited proliferation of $16 \mathrm{~Gy}$-irradiated VSMCs, and showed greater antiproliferative efficacy than $100 \mu \mathrm{M}$ sulfasalazine, a specific NF$\kappa B$ inhibitor. These results indicate that $N F-\kappa B$ inhibition reduces proliferation and survival of irradiated VSMCS, likely by increased apoptosis rather than additive cell cycle arrest and suggest the possibility of adjunctive gene therapy using NF-KB decoy to improve efficacy and to decrease the adverse effects of intracoronary radiation therapy.

Keywords: gene therapy; NF-кB; radiation; vascular smooth muscle cells

\section{Introduction}

Restenosis is one of the most important problems in coronary angioplasty, and its major mechanisms are vascular remodeling and neointimal proliferation (Rajagopal and Rockson, 2003). Although the stent has significantly improved problems associated with negative remodeling, neointimal proliferation has still remained a big challenge for the clinician. Therefore, the inhibition of vascular smooth muscle cell (VSMC) proliferation, which constitutes the major portion of the neointima, is the main target of therapy in restenosis prevention. Accordingly, intracoronary radiation therapy (or coronary brachytherapy), is one of the most promising anti-restenotic modalities due to its antiproliferative, proapoptotic effects along with cell cycle arrest (Teirstein et al., 1997). However, VSMCs are relatively resistant to radiation (Brenner et al., 1996) compared with other cells and intracoronary radiation has been shown to have some adverse side effects at high doses such as late thrombosis and coronary artery aneurysm (Condado et al., 1999; Farb et al., 2003). Therefore, the development of adjunctive therapy is necessary, both to enhance the antiproliferative effects, and to decrease the dose and subsequent adverse effects of coronary brachytherapy.

Exposure of cells to radiation activates different kinds of transcriptional factors such as NF- $\kappa B$ and 
p53 (Li and Karin, 1998; Jonathan et al., 1999). Radiation is known to activate NF- $\mathrm{B}$ B through IKK (I $\mathrm{KB}$ kinase) activation (Li and Karin, 1998). Although NF$\kappa B$ was initially considered as a pro-apoptotic factor because of its rapid activation in response to apoptotic signals and its involvement in the expression of apoptotic genes, such as TNF- $\alpha$ and c-myc, recent work have revealed an anti-apoptotic effect of NF-KB in response to a variety of apoptotic stimuli (Chen et al., 2001) including radiation. Therefore, we postulated that the blocking of NF-KB might potentiate the antiproliferative effects of irradiation in VSMCs. This in vitro study was performed to elucidate the additive effects of $N F-\kappa B$ inhibition on the proliferation and apoptosis of irradiated VSMCs, and its effect on the cell cycle.

\section{Materials and Methods}

\section{Cell culture}

VSMCs were isolated enzymatically from thoracic aorta of male 6-week-old Sprague-Dawley rats. Cells were cultured in Dulbecco's modified Eagle's medium (DMEM)/nutrient mixture F12 (1:1) containing 10\% heat-inactivated fetal bovine serum (Life Technologies, Rockville, MD) and antibiotics (100 U/ml penicillin and $100 \mu \mathrm{g} / \mathrm{ml}$ streptomycin). Culture plates were maintained in the humidified incubator at $37^{\circ} \mathrm{C}$ with a $5 \% \quad \mathrm{CO}_{2}$ atmosphere. The cells were subcultured after treatment with $0.05 \%$ trypsin and $0.53 \mathrm{mM}$ EDTA. Subconfluent cells at passages 4-7 were used for the experiment.

\section{NF- $\mathrm{B} B$ decoy oligodeoxynucleotides}

The sequences of phosphorothioate double-stranded decoy oligodeoxynucleotides against the NF- $\kappa B$ binding site and scrambled oligodeoxynucleotides used in this study were reported previously (Neish et al., 1992; Tomita et al., 1998). Their sequences are as follows: NF- $\kappa B$ decoy oligodeoxynucleotides (5'-CCT TGAAGGGATTTCCCTCC-3'/3'-GGAACTTCCCTA AAGGGAGG-5'), Scrambled oligodeoxynucleotides (5'TTGCCGTACCTGACTTAGCC-3'/3'-AACGGCATGG ACTGAATCGG-5').

Synthetic oligodeoxynucleotides were washed with $70 \%$ ethanol, dried, and dissolved in sterile TRISEDTA buffer (10 mmol/l TRIS and $1 \mathrm{mmol} / / \mathrm{EDTA})$. The supernatant was purified on a nucleic acid purification column (NAP-10 Column; Pharmacia LKB Biotechnology, Piscataway, NJ), and the concentrations of oligodeoxynucleotides were quantified by spectrophotometry. The single-stranded oligodeoxynucleotides were annealed for $2 \mathrm{~h}$ while the temperature descended from 80 to $25^{\circ} \mathrm{C}$.

\section{Transfection of oligodeoxynucleotides}

Cationic liposomes (Lipofectamine; Life Technologies, Rockville, MD) were used as the transfection vectors for oligodeoxynucleotides into VSMCs. This reagent is a 3:1 (wt:wt) liposome formulation of 2,3-dioleyloxy$\mathrm{N}$-[2(sperminecarbox-amido) ethyl]-N,N-dimethyl-I-propanaminium trifuoro-acetate (DOSPA) and the neutral lipid dioleoyl phosphatidylethanolamine (DOPE) in membrane-filtered water. Lipid-oligodeoxynucleotides complexes were formed by adding $10 \mu \mathrm{g}$ lipid in 300 $\mu l$ OPTI-MEM (Life Technologies, Rockville, MD) to $3.3 \mu \mathrm{g}$ oligodeoxynucleotides in $300 \mathrm{ml}$ OPTI-MEM. The solution was mixed gently and incubated at room temperature for $45 \mathrm{~min}$ to allow liposomes to form. Then $30 \mu \mathrm{g}$ lipid was used per $75 \mathrm{~cm}^{2}$ flask to give a final concentration of $2 \mu \mathrm{mol} / /$ decoy. VSMCs were rendered quiescent by placing them for $24 \mathrm{~h}$ prior to transfection in DMEM/F12 medium without fetal bovine serum. Just before transfection, cells were washed with OPTI-MEM medium and then incubated for $3 \mathrm{~h}$ at $37^{\circ} \mathrm{C}$ with freshly prepared liposome-oligodeoxynucleotide complexes. VSMCs were then washed with DMEM/F12 medium and culture was maintained in DMEM/F12 medium without serum at $37^{\circ} \mathrm{C}$ with $5 \%$ $\mathrm{CO}_{2}$ condition. After confirming that the dose of oligdeoxynucleotides and liposomes used, had no immediate toxic effects on cell viability, fetal bovine serum was added to the culture medium $16 \mathrm{~h}$ later. Stable transgene effects were evaluated using fluorescence microscopy to detect fluorescein-labeled oligodeoxynucleotides in transfected cells at $100 \mathrm{~h}$ after gene transfection. 5'-fluorescein labeling was mediated by T4 polynucleotide kinase (Promega, Madison, WI).

\section{$\gamma$-Irradiation treatment}

Forty hours after gene transfection of either $10 \mu \mathrm{M}$ scrambled or NF-kB decoy oligodeoxynucleotides, cells were exposed to $0,2,8$, and 16 Gy $\gamma$-ray irradiation, using a $137-\mathrm{Cs}$ source delivering $3 \mathrm{~Gy} / \mathrm{min}$ at room temperature. They were then harvested at 24 and $48 \mathrm{~h}$ after radiation by suspension in trypsin and stored at $-70^{\circ} \mathrm{C}$ until assay. NF- $\mathrm{kB}$ status after radiation was evaluated by using the rabbit polyclonal antibody to NF-kB p65 (Santa Cruz, Santa Cruz, CA) as primary antibody and FITC-tagged goat anti-rabbit $\lg \mathrm{G}$ (Biodesign, Saco, ME) as secondary antibody.

\section{Nuclear extraction and NF- $\kappa B$ translocation assay}

Samples were harvested $24 \mathrm{~h}$ after oligonucleotide transfection and radiation treatment and washed with PBS. Samples were then placed in cold buffer A (10 $\mathrm{mM}$ HEPES-KOH (pH7.9), $1.5 \mathrm{mM} \mathrm{MgCl}, 10 \mathrm{mM}$ $\mathrm{KCl}, 0.5 \mathrm{mM}$ DTT, $0.2 \mathrm{mM}$ PMSF) for $10 \mathrm{~min}$. Cell lysates were centrifuged at $1,500 \mathrm{rpm}$, retreated with cold buffer B (20 mM HEPES-KOH (pH7.9), 25\% glycerol, $420 \mathrm{mM} \mathrm{Nacl}, 1.5 \mathrm{mM} \mathrm{MgCl}, 0.2 \mathrm{mM}$ EDTA. $0.5 \mathrm{mM}$ DTT, $0.2 \mathrm{mM}$ PMSF), centrifuged again and the supernatant was extracted.

To measure DNA binding, a NF- $\mathrm{B}$ translocation assay was performed using Mercury TransFactor Kit purchased from BD Biosciences (Palo Alto, CA) following the manufacturer's instructions. Briefly, nuclear extracts were probed on a well coated with cis-acting 
DNA element for NF-kB binding site and treated with primary and secondary antibodies. After adding substrate and the stop solution $10 \mathrm{~min}$ later, the absorbance was measured at $450 \mathrm{~nm}$.

\section{Reverse transcriptase-polymerase chain reaction (RT-PCR)}

Primers used for RT-PCR were as follows: TNF- $\alpha$; $F$ : 5'-CATGATCCGAGATGTGGAACTGGC-3', R: 5'-CTG GCTCAGCCACTCCAGC-3', ICAM-1; F: 5'-CCTTAG GAAGGTGTGATATCCGG-3', R: 5'-AGGTGGTCACC CATGCTGGTGCT-3', iNOS; F: 5'-TCATGATGAAAGA ACTCGGG-3', R: 5'-GAAGGTGAGTTGAACAAGGA-3', GAPDH; F: 5'ACCACAGTCCATGCCATCAC-3', R: 5'TCCACCACCCTGTTGCTGTA-3'.

Total RNA was isolated using TRIzol reagent (Gibco-BRL, Grand Island, NY). cDNA was acquired by a Reverse Transcription system (Promega, Tokyo, Japan) using $1 \mu \mathrm{l}$ of total mRNA. PCR reactions contained $1 \mu \mathrm{M}$ primers, $1.5 \mathrm{mM} \mathrm{MgCl}_{2}, 200 \mathrm{uM}$ dNTP (deoxynucleotide triphosphate), reaction buffer, $2.5 \mathrm{U}$ Taq DNA polymerase (Promega, Tokyo, Japan), and $1 \mu$ of cDNA in a final volume of $20 \mu \mathrm{l}$. PCR conditions were 25 cycles of denaturation at $94^{\circ} \mathrm{C}(45 \mathrm{~s})$, primer annealing at different temperatures for each primer (45 s), extension at $72^{\circ} \mathrm{C}(85$ $\mathrm{s})$, and final extension at $72^{\circ} \mathrm{C}(5 \mathrm{~min})$. The PCR products were size fractionated on $1.5 \%$ agarose gel.

\section{Western blotting}

The following antibodies were used in the present study: anti-TNF- $\alpha$, anti-NOS2, and anti-ICAM-1 were obtained from Santa Cruz Biotechnology (Santa Cruz, Calif.); and anti- $\alpha$-tubulin was obtained from Oncogene Research Products (Darmstadt, Germany) Cell lysates were prepared with an ice-cold lysis buffer containing the following: $1 \mathrm{M}$ Tris $(\mathrm{pH} 7.2), 5 \mathrm{M} \mathrm{Nacl}$, NP40, $10 \%$ SDS, 0.5 M EDTA, Deoxycholic acid, beta-glyerophosphate, $\mathrm{NaF}$, protease inhibitor, sodium banadate. Equal amounts of protein were electrophoresed on polyacrylamide gels and transferred to polyvinylidene difluoride membranes (Millipore, Billerica, MA). Membranes were blocked with $5 \%$ nonfat dry milk $(0.1 \%$ TBS-T). Positive antibody reactions were visualized with peroxidase-conjugated anti-mouse immunoglobulin G (Amersham Pharmacia, Piscataway, $\mathrm{NJ}$ ). The peroxidase reaction was performed using an enhanced chemiluminescence detection system (Amersham Pharmacia). The same membrane was reprobed for detection of a different antibody after treatment of the membrane with Restore Western blot stripping buffer (Pierce, Rockford, IL).

\section{Cell proliferation and survival assay}

To measure cellular viability and proliferation, the MTT assay using 3-(4,5-dimethylthiazol-2-yl)-2,5-diphenyl-2H-tetrazoliumbromide was used. Five thousand cells were seeded into a flat-bottomed 96-wellplate and incubated at $37^{\circ} \mathrm{C}$ in a humidified $5 \% \mathrm{CO}_{2}$ condition. At an appropriate time interval, MTT (2 $\mathrm{mg} / \mathrm{ml}$ in PBS) was added to the wells. After incubation for $4 \mathrm{~h}$, the resulting color reaction product, MTT formazan, was extracted with dimethyl sulfoxide and the absorbance was measured at $570 \mathrm{~nm}$. Each absorbance value were normalized by the results of NF- $\mathrm{B} B$ non-inhibited (scrambled oligonucleotide transfected), non-radiated VSMCs (at $24 \mathrm{~h}$ after radiation). The means $\pm S D$ (standard deviation) were calculated from the data of 11 sets of microtiter culture plates in each group.

To compare the antiproliferative efficacy of $N F-\kappa B$ decoy oligonucleotides and sulfasalazine, a specific

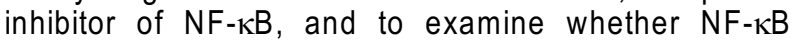
decoy has dose-dependent effects, we compared the survival of VSMCs treated with $10 \mu \mathrm{M}$ scrambled oligonucleotide, $10 \mu \mathrm{M} \mathrm{NF- \kappa B}$ decoy oligonucleotide, $20 \mu \mathrm{M} \mathrm{NF- \kappa B}$ decoy nucleotide, or $100 \mu \mathrm{M}$ of sulfasalazine, all exposed to $16 \mathrm{~Gy}$ radiation. For this analysis, we performed direct cell counting and arbitrarily designated the first measured cell count in the scrambled oligonucleotide group as $100 \%$. All of the other measurements were cell counts relative to the first measurment.

\section{Flow cytometry}

VSMCs were cultured in $75-\mathrm{cm}^{2}$ flasks, and the irradiated cells were harvested by trypsinization. The percentages of the cells in each cell cycle phase were estimated with the flow cytometry method. Briefly, the cells were washed with PBS $(\mathrm{pH} 7.4)$, and then fixed with ice-cold $70 \%$ ethanol at $4^{\circ} \mathrm{C}$ for $4 \mathrm{~h}$. The fixed cells were washed with PBS, and incubated for 30 $\mathrm{min}$ at room temperature with $200 \mu \mathrm{g} / \mathrm{ml}$ RNase A in PBS. Then, propidium iodide solution $(50 \mu \mathrm{g} / \mathrm{ml})$ was added. Flow cytometric analysis was performed on FACStar Plus (Becton Dickinson, Franklin Lakes, NJ).

\section{Statistical analysis}

Quantified results were expressed as mean \pm SD. For non-parametric analysis, Mann-Whitney and Kruskall-Wallis tests were used. Comparison of cell-cycle phase proportions between two groups was performed by $\chi^{2}$ tests. SPSS 11.0 was used for the statistical analysis, and $P<0.05$ was considered statistically significant. All experiments were carried out at least 4 times.

\section{Results}

\section{NF- $\kappa B$ decoy transfection and inhibition of NF- $\kappa B$}

Radiation induced NF- $\mathrm{KB}$ activation and its nuclear translocation was confirmed by immunofluorescence for NF-kB p65 (Figure 1A). DNA binding analysis carried out to confirm the inhibition of $N F-\kappa B$ activation by NF-KB decoy transfection, showed that the increase in DNA binding by NF-kB after irradiation was 
A

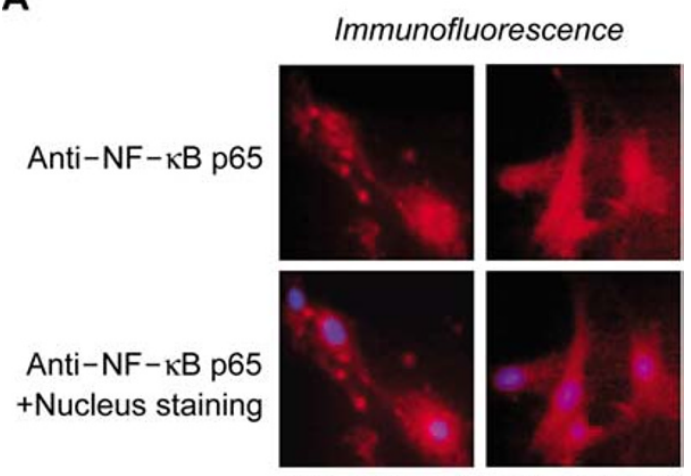

Pre-radiation Post-radiation
B

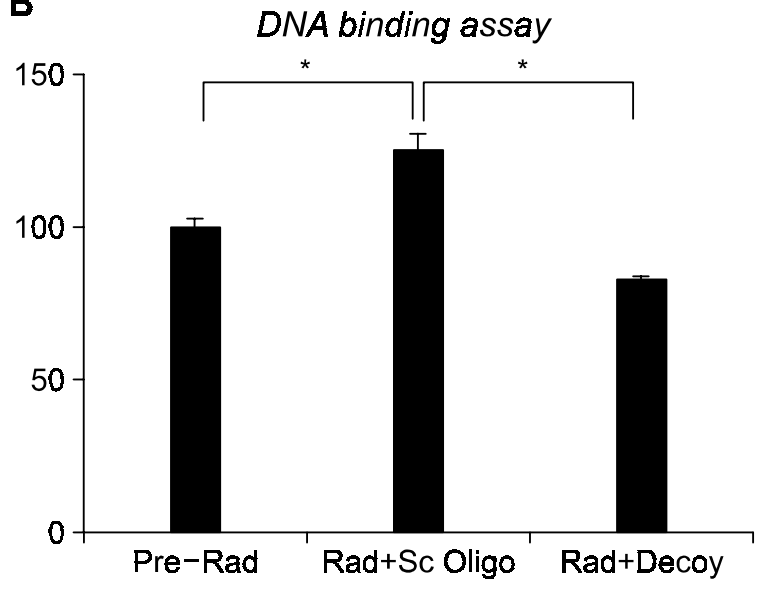

D

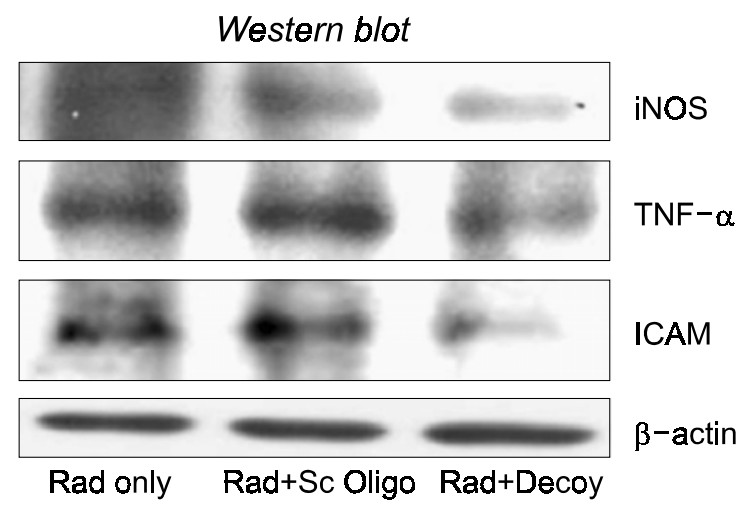

Figure 1. Activation of NF-kB by radiation and its inhibition by NF-kB decoy transfection. Immunofluorescence staining against NF- $\mathrm{kB} p 65$ (red) and merging of the blue stained nucleus showed intranuclear translocation of NF-kB after irradiation (A). DNA binding assay showed inhibition of NF-KB activation by decoy oligodeoxynucleotides. (B). RT-PCR of iNOS, TNF- $\alpha$, and ICAM, showed that NF-KB decoy transfection reduces transcription of downstream molecules of NF-KB (C), and Western blot analysis showed consequent reduced protein translation (D), confirming inhibition of NF-kB by decoy oligodeoxynuclotides. Rad: 16 Gy radiation (3 Gy/min $\times 320 \mathrm{~s}$ ), Sc Oligo: $10 \mu \mathrm{M}$ scrambled oligodeoxynucleotide, Decoy: $10 \mu \mathrm{M}$ NF-kB decoy oligodeoxynucleotide. ${ }^{*} P<0.05$.

significantly inhibited by NF-KB decoy transfection (Figure 1B). In addition, RT-PCR and Western blot analysis showed that NF- $\kappa B$ decoy transfection decreased transcription and translation of ICAM, iNOS, and TNF- $\alpha$, downstream molecules of NF- $\mathrm{KB}$, confirming $N F-\kappa B$ inhibition (Figure $1 C$ and $D$ ).

\section{Effects of NF-KB inhibition on irradiated VSMC proliferation and survival}

In the non-radiated VSMCs, NF-KB decoy transfection did not show any significant effects on cell survival. However, in the irradiated VSMCs, NF-kB decoy transfection resulted in significant inhibition of VSMC survival and proliferation. At 2 and $8-G y$ exposure, radiation only resulted in increased survival of VSMCs compared to non-radiated cells at $24 \mathrm{~h}$ after radiation, while exposure to $16-\mathrm{Gy}$ radiation resulted in decreased survival of VSMCs. The transfection of NF$\kappa B$ decoy in addition to radiation, decreased cellular survival at all doses of radiation compared with scrambled oligonucleotide transfection, although results were only statistically significant at 8 and 16-Gy (normalized MTT assay: $1.47 \pm 0.19$ vs. $0.92 \pm 0.12$, and $0.82 \pm 0.24$ vs. $0.64 \pm 0.09$ for $8-G y$ and 16-Gy NF-kB non-inhibited vs. inhibited, respectively, $P<0.01)$. At $48 \mathrm{~h}$ after radiation, the increase in survival of VSMCs exposed to 2 and 8-Gy radiation and the decrease in survival of cells exposed to 16Gy radiation compared with non-radiated cells were similar to what was observed at $24 \mathrm{~h}$. However at $48 \mathrm{~h}, \mathrm{NF}-\kappa \mathrm{B}$ decoy transfection significantly inhibited proliferation and survival of VSMCs at all doses of radiation compared with scrambled oligonucleotide transfection (normalized MTT assay: $1.47 \pm 0.34$ vs. $1.06 \pm 0.16, \quad 1.56 \pm 0.32$ vs. $1.11 \pm 0.22$, and 1.20 \pm 0.25 vs. $0.67 \pm 0.19$, for 2,8 , and $16-G y$ NF-kB non-inhibited vs. inhibited, respectively, $P<0.01$ ) (Figure $2 \mathrm{~A}$ and $\mathrm{B}$ ). The enhanced inhibition of VSMC survival and proliferation by NF-kB inhibition was such 

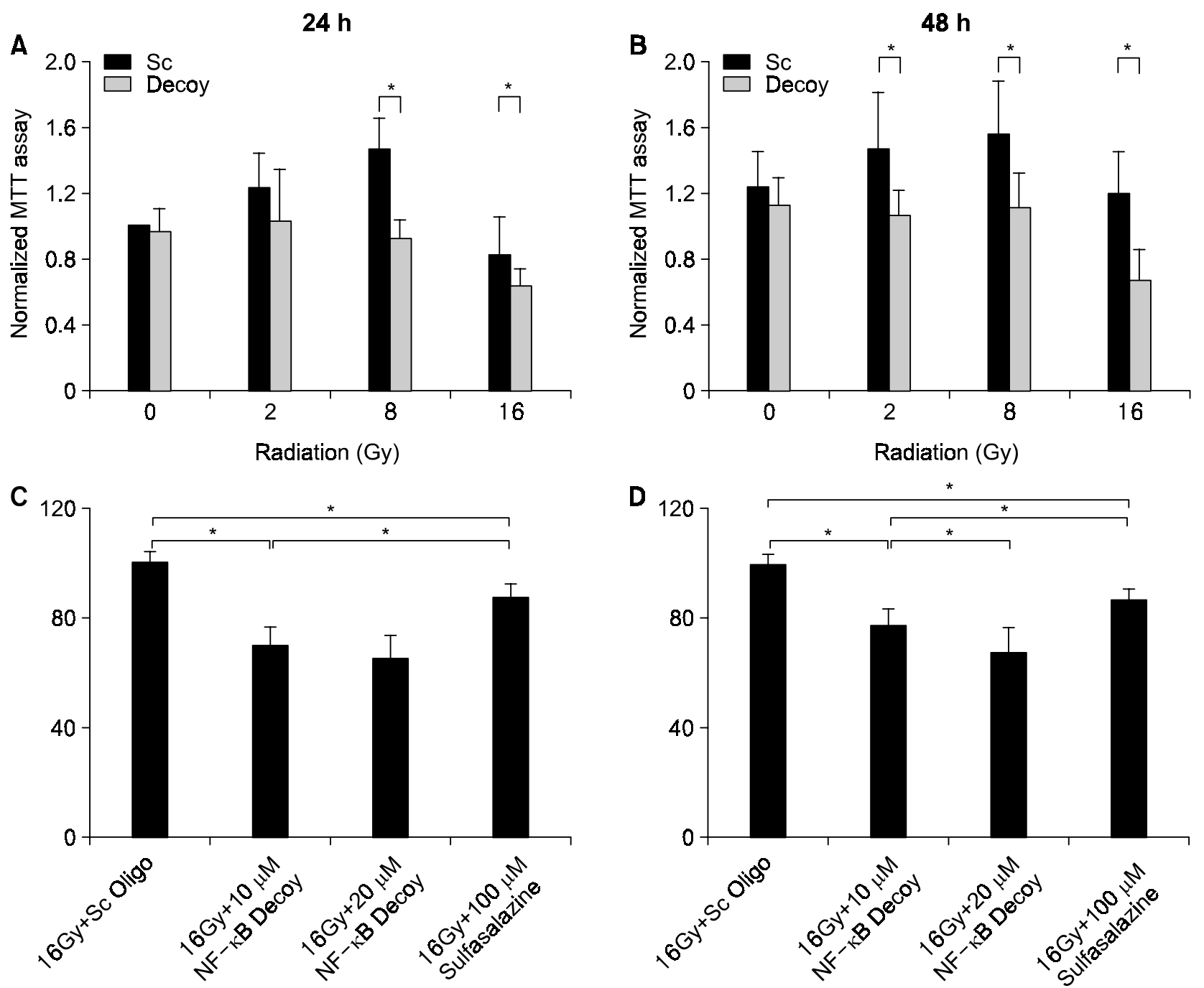

Figure 2. Cell survival assay. $10 \mu \mathrm{M} \mathrm{NF- \kappa B}$ decoy transfection resulted in a significant decrease in survival and inhibition of proliferation in VSMCs exposed to 8 and $16 \mathrm{~Gy}$ at $24 \mathrm{~h}(\mathrm{~A})$, and to all doses of radiation at $48 \mathrm{~h}$ (B). Although insignificant at $24 \mathrm{~h}(\mathrm{C}), \mathrm{NF}-\mathrm{kB}$ decoy treatment showed a dose responsive effect on celluluar survival at $48 \mathrm{~h}$ in 16 Gy-irradiated VSMCs. The efficacy of NF-kB decoy was also compared with that of $100 \mu \mathrm{M}$ sulfasalazine, a specific NF-kB inhibitor, which showed that even the lower dose of NF-kB decoy $(10 \mu \mathrm{M})$ had a greater inhibitory effect on $16 \mathrm{~Gy}$ irradiated VSMCs than $100 \mu \mathrm{M}$ sulfasalazine at both 24 and $48 \mathrm{~h}$ as shown by direct cell counting (C \& D). Rad: radiation, Sc Oligo: scrambled oligodeoxynucleotides, Decoy: NF-KB decoy oligodeoxynucleotides. *: $P<0.05$, NS: not significant. Each absorbance value of MTT assay was normalized by the results of NF-kB non-inhibited non-radiated VSMCs at $24 \mathrm{~h}$.

that at $48 \mathrm{~h}$ after radiation, the effects of 2 and $8-\mathrm{Gy}$ radiation combined with $\mathrm{NF}-\kappa \mathrm{B}$ decoy transfection $(1.06 \pm 0.16$ and $1.11 \pm 0.22$, respectively) were comparable to that of $16-\mathrm{Gy}$ radiation alone without NF- $\mathrm{KB}$ inhibition $(1.20 \pm 0.25)$.

In addition, we observed a dose-dependent effect of NF-kB decoy on cell survival. At $48 \mathrm{~h}$ in VSMCs exposed to $16 \mathrm{~Gy}$ radiation, $20 \mu \mathrm{M} N F-\kappa B$ decoy transfection showed a further reduction in cell survival from $10 \mu \mathrm{M}$ NF- $\mathrm{KB}$ decoy transfection, (cell survival: $99.9 \% \pm 8.8$ vs. $71.1 \% \pm 21.3$ vs. $60.7 \% \pm 15.4$ for scrambled oligonucleotide vs. $10 \mu \mathrm{M}$ NF-кB decoy oligonucleotide vs. $20 \mu \mathrm{M} N F-\kappa B$ decoy oligonucleo- tide, $n=4, P<0.05)$. Moreover, when the antiproliferative efficacy of NF- $\mathrm{KB}$ decoy was compared with that of sulfasalazine, a specific inhibitor of $N F-\kappa B$, the effects of either 10 and $20 \mu \mathrm{M} \mathrm{NF- \kappa B}$ decoy transfection was greater than that of $100 \mathrm{mM}$ sulfasalazine (cell survival: $99.9 \% \pm 8.8$ vs. $71.1 \% \pm 21.3$ vs. $60.7 \% \pm 15.4$ vs. $85.1 \% \pm 15.1$ for scrambled oligonucleotide vs. $10 \mathrm{mM} \mathrm{NF- \kappa B}$ decoy oligonucleotide vs. $20 \mu \mathrm{M}$ NF- $\kappa B$ decoy oligonucleotide vs. $100 \mu \mathrm{M}$ sulfasalazine, $n=4, P<0.05)$. 

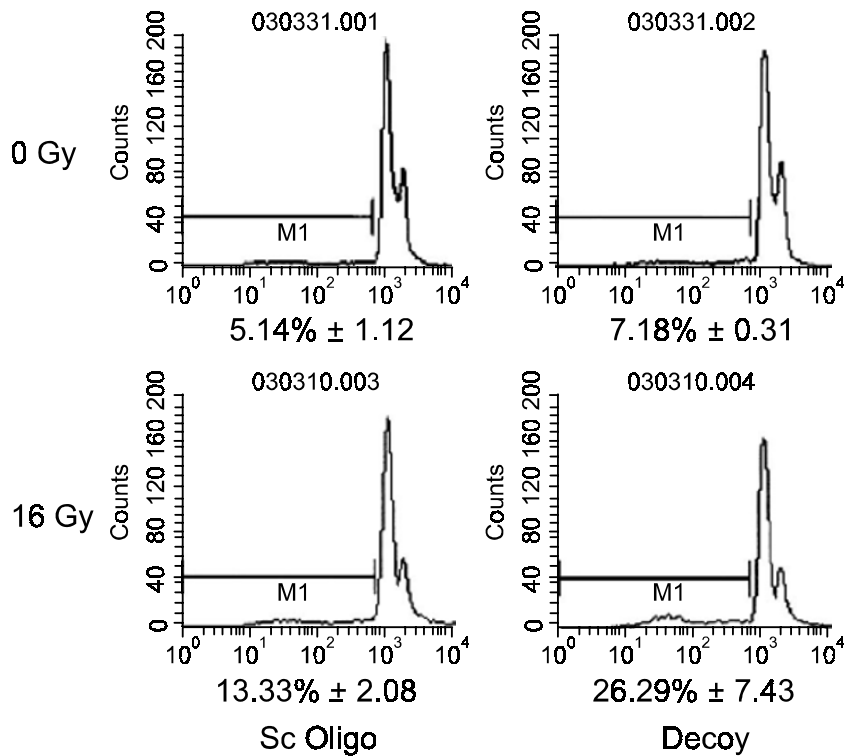

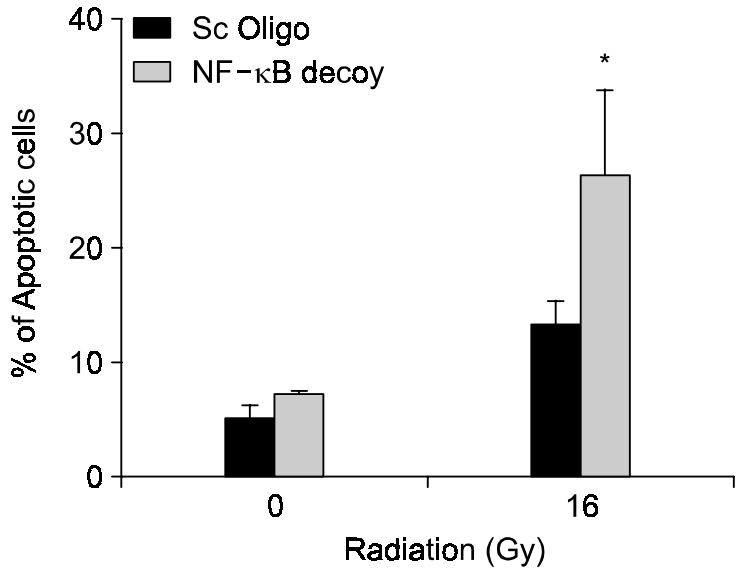

Figure 3. Apoptosis assay. FACS analysis showed that the increase in apoptosis of VSMCs by NF-кB decoy became more significant in 16 Gy-irradiated cells. Sc Oligo: scrambled oligodeoxynucleotides, Decoy: $10 \mu \mathrm{M} \mathrm{NF- \kappa B}$ decoy oligodeoxynucleotides. Proportion of apoptosis cells given as mean \pm standard deviation. *: $P<0.05$ vs. scrambed oligodeoxynucleotide treated $\operatorname{VSMCs}(n=5)$.

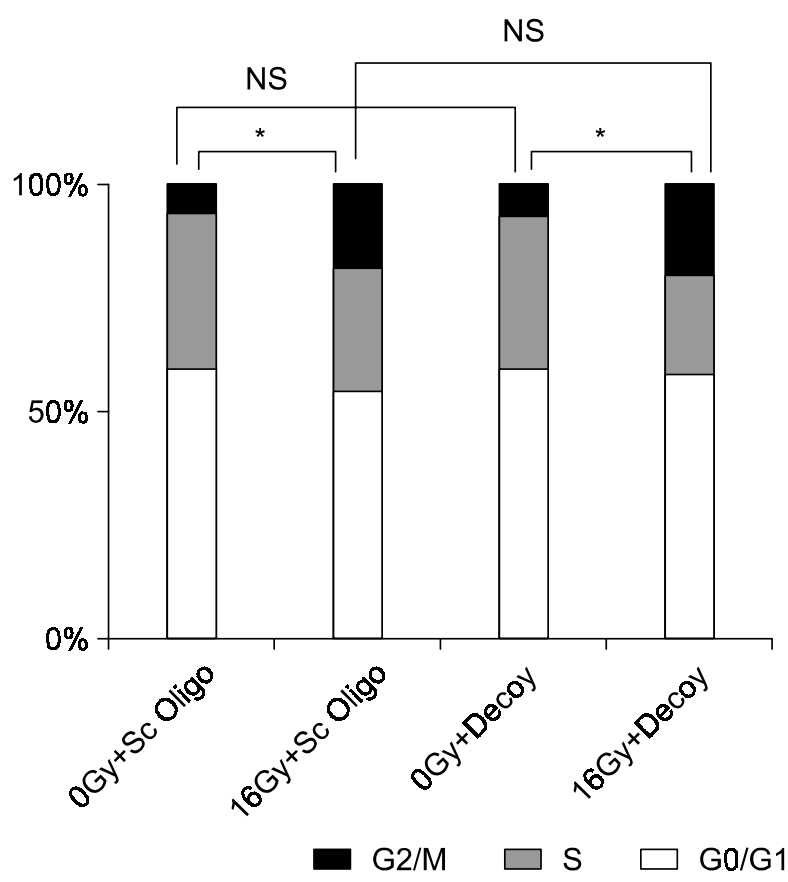

Figure 4. Cell cycle analysis. Radiation exposure resulted in a significant increase in the number of VSMCs in the G2/M phase, and decreased cells in the S-phase, a profile of $G 2$ arrest as measured by FACS analysis of the cell cycle. However, compared with scrambled oligodeoxynucleotide treatment, transfection of NF-kB decoy oligodeoxynucleotide did not result in any significant additive effects on the cell cycle. Sc Oligo: scrambled oligodeoxynucleotides, Decoy: $10 \mu \mathrm{M}$ NF-KB decoy oligodeoxynucleotides. *: $P<0.05$, NS: not significant.

\section{Effects of NF-KB inhibition on irradiated VSMC apoptosis}

FACS analysis showed that the proportion of apoptotic cells significantly increased after radiation treatment (apoptosis fraction: $5.14 \pm 1.12 \%$ vs. $13.33 \pm$ $2.08 \%, P<0.05$ ). Furthermore, the apoptotic fraction of irradiated VSMCs was significantly increased by NF- $\kappa B$ decoy transfection $(13.33 \pm 2.08 \%$ vs. $26.29 \pm 7.43 \%, P<0.05)$ showing that NF-kB inhibition significantly enhanced the proapoptotic effects of radiation (Figure 3 ).

\section{Effects of NF-KB inhibition on the cell cycle of irradiated VSMCs}

$\gamma$-ray irradiation itself induced cell cycle arrest, reducing the percentage of cells in the S-phase and increasing the percentage of cells in the $G 2 / M$ phase, a typical profile of $\mathrm{G} 2$ arrest (G0/G1:S:G2/M $=59 \%$ : $35 \%: 6 \%$ vs. $54 \%: 28 \%: 18 \%$, non-radiated vs. $16-\mathrm{Gy}$ radiated cells at $24 \mathrm{~h}$ after radiation, $P<0.01$ ). Further inhibition of NF-KB in irradiated VSMCs, did not show any additional effects in terms of cell cycle arrest (G0/G1:S:G2/M = 54\%:28\%:18\% vs. $58 \%: 22 \%$ : $20 \%$, NF- $\mathrm{kB}$ non-inhibited vs. inhibited in $16-\mathrm{Gy}$ radiated cells at $24 \mathrm{~h}, P=0.348$ ) (Figure 4).

\section{Discussion}

$\mathrm{NF}-\mathrm{KB}$, a cell survival factor activated by radiation in VSMCs, may render such cells to be relatively radioresistent. Such radioresistence requires us to use high doses of local radiation to inhibit VSMC proli- 
feration and neointimal growth after angioplasty in clinical practice during coronary brachytherapy. Therefore, we studied whether inhibition of NF-KB through NF- $\mathrm{KB}$ decoy transfection would potentiate the antiproliferative effects of radiation. We showed that NF$\kappa B$ decoy transfection inhibits the activation of NF- $\kappa B$ and its subsequent transcription and translation of downstream molecules. We also found that such inhibition of NF- $\kappa B$ leads to decreased survival and proliferation of irradiated VSMCs, which seem to be due to increased apoptosis of VSMCs rather than additional cell cycle arrest.

It is well-known that ionizing radiation including $\gamma$-rays activates NF-KB (Li and Karin, 1998). We postulated that inhibition of NF-KB activation would reduce survival and inhibit proliferation of irradiated VSMCs. In the present study, NF- $\kappa B$ inhibition significantly reduced survival and proliferation of VSMCs exposed to 8 and 16-Gy radiation at $24 \mathrm{~h}$ and all doses of radiation at $48 \mathrm{~h}$. However NF-kB decoy transfection had no significant effects on non-radiated VSMCs. Due to the fact that NF-KB in resting cells is sequestered in the cytoplasm bound to $I_{\kappa} B_{\alpha}$ and $I_{\kappa} B_{\beta}$ (Baldwin, 1996), we believe that NF- $\kappa B$ inhibition by decoy oligodeoxynucleotides has little effect under conditions where NF- $\mathrm{KB}$ is not activated, such as non-radiated VSMCs in serum-rich culture conditions.

In addition, the efficacy of $10 \mu \mathrm{M} N F-\kappa B$ decoy, at both 24 and $48 \mathrm{~h}$, was greater than that of 100 $\mu \mathrm{M}$ sulfasalazine, a specific inhibitor of $N F-\kappa B$. Furthermore, the effect of $20 \mu \mathrm{M} N F-\kappa B$ decoy was greater than that of $10 \mu \mathrm{M} N F-\kappa B$ decoy at $48 \mathrm{~h}$, suggesting a dose dependent effect of NF-KB decoy.

$\mathrm{NF}-\kappa \mathrm{B}$ has been shown in various cells to have an anti-apoptotic effect. Impaired NF- $\kappa B$ has been associated with massive apoptosis during development in several gene knockout studies ( $\mathrm{Li}$ et al., 1999; Tanaka et al., 1999). In addition, NF-кB has been shown to protect neurons from beta-amyloid peptide induced apoptosis in Alzheimer's disease (Bales et al., 1998; Guo et al., 1998). Furthermore, NF- $\mathrm{KB}$ inhibition using decoy oligonucleotide was associated with enhanced apoptosis in neuronal cells (Guo et al., 1998), and with TNF- $\alpha$ induced apoptosis in prostate cancer cell lines (Sumitomo et al., 1999). In the present study, the simple inhibition of $N F-\kappa B$, in non-radiated VSMCs, showed only minimally increased apoptosis, which were not statistically significant $(5.14 \pm 1.12 \%$ vs. $7.18 \pm 0.31 \%$, for NF- $\mathrm{KB}$ non-inhibited vs. inhibited, $P>0.05)$. However, in irradiated VSMCs, NF-KB inhibition resulted in a significantly increased apoptotic cell fraction (13.33 \pm $2.08 \%$ vs. $26.29 \pm 7.43 \%$, for NF- $\kappa B$ non-inhibited vs. inhibited, $P<0.05)$.

lonizing radiation is known to induce cell cycle arrest (Brugarolas et al., 1995; Scott et al., 2001). Radiation activates p53 via ATM, which subsequently, activates $\mathrm{p} 21^{\text {Waf- }-1}$, a cdk inhibitor that induces $\mathrm{G} 1$ and $\mathrm{G} 2$ arrest by cdk/cyclin inhibition (Jonathan et al., 1999). In contrast to the established data on the role of radiation, relatively little is known regarding the role of $N F-\kappa B$ in the progression of the cell cycle. There has been a conflicting evidence on whether NF- $\kappa B$ is important in the progression or the arrest of the cell cycle. Some have reported that NF- $\kappa B$ activation is necessary to cause cell cycle arrest (Bash et al., 1997). However the body of evidence in recent studies have shown that NF-KB activation is related to cell cycle progression rather than arrest in various cell types (Baldwin et al., 1991; Cressman et al., 1994; Yamada et al., 1997), and that NF-KB inhibition results in cell cycle arrest (Kaltschmidt et al., 1999; Otsuka et al., 1999). Radiation has bi-directional effects on p53; it can activate p53 via ATM (Herzog et al., 1998; Jonathan et al., 1999) and simultaneously activates NF-KB (Li and Karin, 1998), which may have an inhibitory effect on p53 (Stoffel et al., 2004). Therefore the balance of p53 activation and inhibition may determine the fates of the irradiated cells. In the present study, radiation significantly reduced the fraction of cells in the S-phase and increased cells in the $\mathrm{G} 2 / \mathrm{M}$ phase, a typical profile of G2 phase arrest. However, we could not observe any additive effects of NF- $\kappa B$ inhibition on the irradiated cells. NF-KB decoy treatment in the setting of the present study (dose and culture conditions) may not have altered p53 balance enough to cause a significant change in the cell cycle.

Many clinical studies of intracoronary radiation therapy have reported successful reduction of restenosis (Condado et al., 1997; Teirstein et al., 1997; King et al., 1998; Waksman et al., 2000). The main mechanism of radiation is to inhibit the proliferative response of VSMCs at the site of injury (Waksman et al., 1997). Due to the high doses of radiation, adverse effects such as aneurysmal dilatation of the artery and late thrombosis have been detected in clinical studies (Condado et al., 1999; Farb et al., 2003). These adverse effects may be decreased by low-dose radiation. As the present study shows, lowdose radiation combined with $\mathrm{NF}-\kappa \mathrm{B}$ inhibition may be comparable to the effects of high-dose radiation in regard to VSMC proliferation and survival. Furthermore, the dose dependent effects and efficacy of NF- $\mathrm{B}$ decoy shown in the present study, suggests that it may be a simple and efficacious modality of $N F-\kappa B$ inhibition. It was recently shown that $N F-\kappa B$ decoy reduces neointima in a porcine model of coronary artery injury through inhibition of proinflammatory genes and adhesion molecules (Yamasaki et al., 2003). Furthermore, the authors hypothesized that one of the mechanisms of neointima inhibition, may be the inhibition of injury-activated VSMC proliferation by induction of VSMC apoptosis (Morishita et al., 2004). However, this was not a model of intracoronary radiation but only simple vessel injury. We believe that the effects of NF-kB decoy would be more efficacious in the setting of intracoronary radiation along with vessel injury, which is what goes on after coronary brachytheray.

In conclusion, we found that NF- $\kappa B$ inhibition potentiates the antiproliferative effects of radiation in VSMCs and these effects seem to be through increased apoptosis of VSMCs rather than additional 
cell cycle arrest. Although our in vitro data must be confirmed first in animal models of restenosis and VSMC hyperplasia, the results of the present study suggest the possibility of combined intracoronary radiation with NF- $\mathrm{KB}$ inhibiting gene therapy, so called "radiogene therapy", to inhibit VSMC proliferation and neointimal growth after angioplasty.

\section{Acknowledgement}

This study was supported by grants from the Korea Health 21 R\&D project, Ministry of Health \& Welfare, Republic of Korea (02-PJ10-PG8-EC01-0026 [Dr. Hyo-Soo Kim]), and the Korea Science and Engineering Foundation (KOSEF) to Dr. Hyo-Soo Kim through the aging and apoptosis research center at Seoul National University, Republic of Korea.

\section{References}

Baldwin AS, Jr, Azizkhan JC, Jensen DE, Beg AA, Coodly LR. Induction of NF-kappa B DNA-binding activity during the G0-to-G1 transition in mouse fibroblasts. Mol Cell Biol 1991; 11:4943-51

Baldwin AS Jr. The NF- $\kappa B$ and $I_{\kappa} B$ proteins: new discoveries and insights. Annu Rev Immunol 1996;14:649-83

Bales KR, Du Y, Dodel RC, Yan GM, Hamilton-Byrd E, Paul SM: The NF-kB/Rel family of proteins mediates Ab-induced neurotoxicity and glial activation. Brain Res Mol Brain Res 1998;57:63-72

Bash J, Zong WX, Gelinas C. C-Rel arrests the proliferation of HeLa cells and affects critical regulators of the G1/Sphase transition. Mol Cell Biol 1997;17:6526-36

Brenner DJ, Miller RC, Hall EJ. The radiobiology of intravascular irradiation. Int J Radiat Oncol Biol Phys 1996;36: 805-10

Brugarolas J, Chandrasekaran C, Gordon JI, Beach D, Jacks T, Hannon GJ. Radiation-induced cell cycle arrest compromised by p21 deficiency. Nature 1995;377:552-7

Chen F, Castranova V, Shi X. New Insights into the Role of Nuclear Factor- $\kappa B$ in Cell Growth Regulation. Am J Pathol 2001;159:387-97

Condado JA, Waksman R, Calderas C, Saucedo J, Lansky A. Two-year follow-up after intracoronary gamma radiation therapy. Cardiovasc Radiat Med 1999;1:30-5

Condado JA, Waksman R, Gurdiel O, Espinosa R, Gonzalez $\mathrm{J}$, Burger B, Villoria G, Acquatella $H$, Crocker IR, Seung KB, Liprie SF. Long-term angiographic and clinical outcome after percutaneous transluminal coronary angioplasty and intracoronary radiation therapy in humans. Circulation 1997;96: 727-32

Cressman DE, Greenbaum LE, Haber BA, Taub R. Rapid activation of post-hepatectomy factor/nuclear factor kappa B in hepatocytes, a primary response in the regenerating liver. $J$ Biol Chem 1994;269:30429-35

Farb A, Burke AP, Kolodgie FD, Virmani R. Pathological mechanisms of fatal late coronary stent thrombosis in humans. Circulation 2003;108:1701-6

Guo Q, Robinson N, Mattson MP: Secreted $\beta$-amyloid precursor protein counteracts the proapoptotic action of mutant presenilin-1 by activation of NF- $\mathrm{KB}$ and stabilization of calcium homeostasis. J Biol Chem 1998;273:12341-51

Herzog KH, Chong MJ, Kapsetaki M, Morgan JI, McKinnon $P$. Requirement for Atm in ionizing radiation-induced cell death in the developing central nervous system. Science 1998;280:1089-91

Jonathan EC, Bernhard EJ, McKenna WG. How does radiation kill cells? Curr Opin Chem Biol 1999;3:77-83

Kaltschmidt B, Kaltschmidt C, Hehner SP, Droge W, Schmitz ML. Repression of NF-kappaB impairs HeLa cell proliferation by functional interference with cell cycle checkpoint regulators. Oncogene 1999;18:3213-25

King SB, 3rd, Williams DO, Chougule P, Klein JL, Waksman R, Hilstead R, Macdonald J, Anderberg K, Crocker IR. Endovascular beta-radiation to reduce restenosis after coronary balloon angioplasty: results of the beta energy restenosis trial (BERT). Circulation 1998;97:2025-30

$\mathrm{Li} N$, Karin $\mathrm{M}$. lonizing radiation and short wavelength UV activate NF-kappaB through two distinct mechanisms. Proc Natl Acad Sci USA 1998;95:13012-7

Li ZW, Chu W, Hu Y, Delhase M, Deerinck T, Ellisman M, Johnson R, Karin $M$ : The $I_{K K}$ subunit of $I_{\kappa} B$ kinase (IKK) is essential for nuclear factor $\mathrm{KB}$ activation and prevention of apoptosis. J Exp Med 1999;189:1839-45

Morishita R, Tomita N, Kaneda Y, Ogihara T. Molecular therapy to inhibit NFkappaB activation by transcription factor decoy oligonucleotides. Curr Opin Pharmacol 2004;4:139-46

Neish AS, Williams AJ, Palmer HJ, Whitley MZ, Collins T. Functional analysis of the human vascular cell adhesion molecule 1 promoter. J Exp Med 1992;176:1583-93

Otsuka G, Nagaya T, Saito K, Mizuno M, Yoshida J, Seo $H$. Inhibition of nuclear factor-kappaB activation confers sensitivity to tumor necrosis factor-alpha by impairment of cell cycle progression in human glioma cells. Cancer Res 1999;59:4446-52

Rajagopal V, Rockson SG. Coronary restenosis: a review of mechanisms and management. Am J Med 2003;115:547-53

Sawa $\mathrm{Y}$, Morishita R, Suzuki K, Kagisaki K, Kaneda $\mathrm{Y}$, Maeda K, Kadoba K, Matsuda H. A novel strategy for myocardial protection using in vivo transfection of cis element 'decoy' against NFkappaB binding site: evidence for a role of NFkappaB in ischemia-reperfusion injury. Circulation. 1997; 96:II-280-284; discussion II-285

Scott NA, Crocker IR, Yin Q, Sorescu D, Wilcox JH, Griendling KK. Inhibition of vascular cell growth by X-ray irradiation: Comparison with gamma radiation and mechanism of action. Int J Radiation Oncology Biol Phys 2001;103: 485-93

Stoffel A, Chaurushiya M, Singh B, Levine AJ. Activation of NF-kappaB and inhibition of p53-mediated apoptosis by API2/mucosa-associated lymphoid tissue 1 fusions promote oncogenesis.Proc Natl Acad Sci USA 2004;101:9079-84 
Sumitomo M, Tachibana M, Nakashima J, Murai M, Miyajima A, Kimura $F$, Hayakawa $M$, Nakamura $H$. An essential role for nuclear factor kappa B in preventing TNF-alpha-induced cell death in prostate cancer cells. J Urol 1999;161:674-9

Tanaka M, Fuentes ME, Yamaguchi K, Durnin MH, Dalrymple SA, Hardy KL, Goeddel DV: Embryonic lethality, liver degeneration, and impaired NF- $\mathrm{KB}$ activation in IKK- $\beta$ deficient mice. Immunity 1999;10:421-9

Teirstein PS, Massullo V, Jani S, Popma JJ, Mintz GS, Russo RJ, Schatz RA, Guarneri EM, Steuterman S, Morris NB, Leon MB, Tripuraneni P. Catheter-Based Radiotherapy to Inhibit Restenosis after Coronary Stenting. N Engl J Med 1997;336:1697-703

Tomita N, Morishita R, Tomita S, Yamamoto K, Aoki M, Matsushita H, Hayashi S, Higaki J, Ogihara T. Transcription factor decoy for nuclear factor-kappaB inhibits tumor necrosis factor-alpha-induced expression of interleukin- 6 and intracellular adhesion molecule-1 in endothelial cells. J Hypertens 1998;16:993-1000
Waksman R, Rodriguez JC, Robinson KA, Cipolla GD, Crocker IR, Scott NA, King SB, Wilcox JN. Effect of intravascular irradiation on cell proliferation, apoptosis, and vascular remodeling after balloon overstretch injury of porcine coronary arteries. Circulation 1997;96:1944-52

Waksman R, White RL, Chan RC, Bass BG, Geirlach L, Mintz GS, Satler LF, Mehran R, Serruys PW, Lansky AJ, Fitzgerald $P$, Bhargava $B$, Kent KM, Pichard $A D$, Leon MB. Intracoronary gamma-Radiation Therapy After Angioplasty Inhibits Recurrence in Patients With In-Stent Restenosis. Circulation 2000;101:2165-71

Yamada Y, Kirillova I, Peschon JJ, Fausto N. Initiation of liver growth by tumor necrosis factor: deficient liver regeneration in mice lacking type I tumor necrosis factor receptor. Proc Natl Acad Sci USA 1997;94:1441-6

Yamasaki K, Asai T,Shimizu M, Aoki M, Hashiya N, Sakonjo $\mathrm{H}$, Makino $\mathrm{H}$, Kaneda $\mathrm{Y}$, Ogihara T, Morishita R. Inhibition of NF- $\kappa B$ activation using cis-element 'decoy' of NF- $\kappa B$ binding site reduces neointimal formation in procine ballooninjured coronary artery model. Gene Ther 2003;10:356-64 